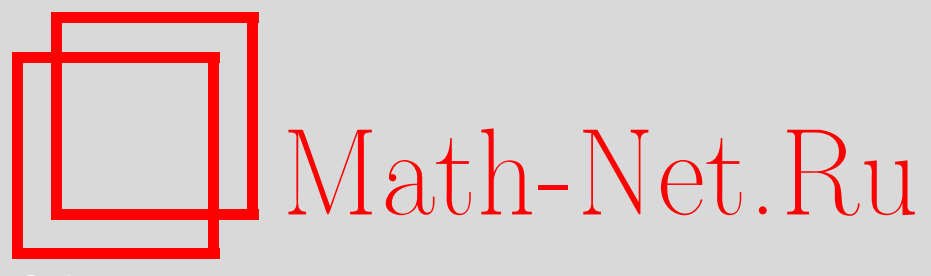

Р. А. Архонтова, А. Г. Баскаков, И. А. Бахтин, Э. С. Беляева, Ю. Г. Борисович, А. С. Греченко, В. Р. Зачепа, А. А. Карацуба, А. Ф. Кудинов, В. В. Обуховский, А. И. Перов, А. С. Потапов, Е. М. Семёнов, В. П. Трофимов, Н. Н. Удоденко, Кирилл Андреевич Родосский (некролог), УМН, 2006, том 61, выпуск 5, 173-175

DOI: https://doi.org/10.4213/rm4492

Использование Общероссийского математического портала Math-Net.Ru подразумевает, что вы прочитали и согласны с пользовательским соглашением http://www.mathnet.ru/rus/agreement

Параметры загрузки:

IP: 3.89 .185 .249

26 апреля 2023 г., $17: 21: 31$

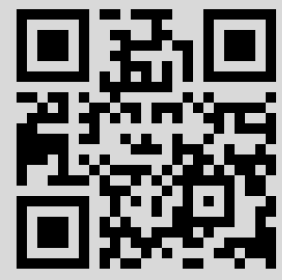




\section{Кирилл Андреевич Родосский}

30 августа 2004 г. на 92-м году жизни после тяжелой и продолжительной болезни скончался доктор физико-математических наук, профессор Кирилл Андреевич Родосский.

Кирилл Андреевич родился 25 февраля 1913 г. в Санкт-Петербурге. Окончив среднюю школу в 1930 г., он начал свою трудовую деятельность на Октябрьском химическом комбинате г. Ленинграда. После убийства С. М. Кирова в декабре 1934 г. в стране начались политические процессы и репрессии. В марте 1935 г. семья Родосских была обвинена в групповой антисоветской агитации и выслана на 5 лет в г. Саратов.

В дни тяжких испытаний Кирилл Андреевич, работая счетоводом, не оставлял свое увлечение шахматами - он стал чемпионом Саратовской области. При этом Кирилл Андреевич продолжал самостоятельно заниматься математикой, кото-

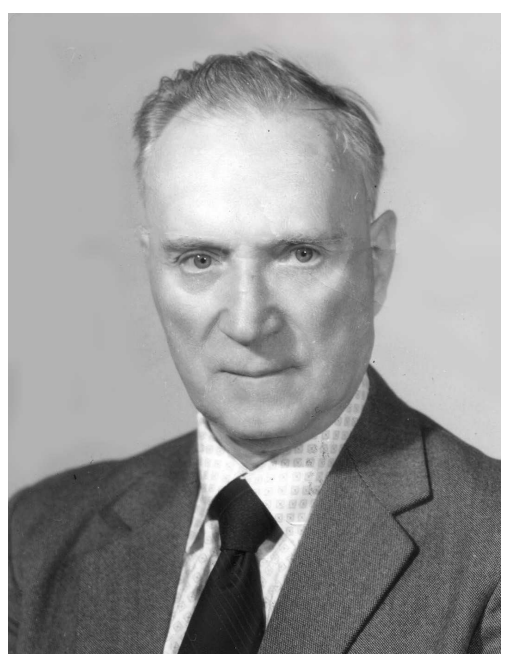
рой увлекался с детства. Необыкновенное трудолюбие, целеустремленность и природный дар помогли ему поступить в 1936 г. сразу на второй курс физико-математического факультета Саратовского государственного университета.

По окончании университета в 1940 г. Кирилл Андреевич Родосский работает ассистентом кафедры математического анализа. Но после создания в этом же году кафедры алгебры и теории чисел под руководством известного ученого профессора Николая Григорьевича Чудакова, который стал его первым учителем, Кирилл Андреевич переходит на эту кафедру.

В 1942 г. Кирилла Андреевича призвали в армию, но вскоре, в связи с тяжелым заболеванием, демобилизовали и направили работать учителем средней школы с. Стригай Саратовской области. Затем, с мая 1944 г. К. А. Родосский проходил нестроевую службу в одном из СМУ г. Саратова, где работал воспитателем молодых рабочих, окончивших ФЗО.

После демобилизации в 1945 г. Кирилл Андреевич снова начал работать по специальности: сначала в Саратовском экономическом институте, затем научным сотрудником в одном из научно-исследовательских институтов, а с 1949 г. - вновь на кафедре алгебры и теории чисел Саратовского государственного университета.

В 1947 г. К. А. Родосский защитил кандидатскую диссертацию на тему "Распределение простых чисел в коротких арифметических прогрессиях". В 1954 г. в Математическом институте им. В. А. Стеклова Академии наук СССР им была защищена докторская диссертация на тему "О нулях $L$-функций и простых числах", которую академик Ю. В. Линник считал "превосходной и выдающейся".

С 1959 г. Кирилл Андреевич заведовал кафедрой алгебры и геометрии математикомеханического факультета Воронежского университета. 
В 1967 г. К. А. Родосский перешел на работу в Воронежский педагогический институт, где заведовал кафедрой алгебры и геометрии до 1975 г. В последующие годы он продолжал работать профессором этой кафедры.

Круг научных интересов К. А. Родосского отличался широтой. Его первые работы были связаны с изучением распределения простых чисел в арифметических прогрессиях $k n+l$, где $n \leqslant N, l$ и $k$ - взаимно простые числа и $k$ растет вместе с $N$. Понятие короткой арифметической прогрессии было введено К. А. Родосским и получило общее признание.

Для количества простых чисел меньших $x$, принадлежащих указанной прогрессии, К. А. Родосским была получена асимптотическая формула при $x \rightarrow \infty$ с достаточно большими значениями для $k$. Кроме того, К. А. Родосский получил асимптотическую формулу для конечной разности функции Чебышева, рассматриваемой в коротких арифметических прогрессиях, которая дополняла результаты Н. Г. Чудакова в связи с этой задачей. ВОн показал также, что асимптотическое приближение функции Чебышева достаточно часто бывает с весьма малой ошибкой.

В ряде работ советских и зарубежных математиков, начиная с 30-х годов прошлого столетия, было показано, что для решения некоторых задач о распределении простых чисел достаточно знать только “плотность нулей" $L$-функций Дирихле, попадающих в так называемую "критическую полосу". В совместной работе Н. Г. Чудакова и К. А. Родосского 1949 г. был дан обзор основных результатов, полученных с помощью свойств плотности нулей. Одной из задач, обсуждавшихся в этом обзоpe, была задача о наименьшем простом числе $p(k, l)$ в арифметической прогрессии. Венгерский математик П. Туран показал, что для $p(k, l)$ имеет место неравенство $p(k, l)<k^{c}$, где $c$ - некоторая абсолютная константа, не зависящая от $k$. Доказательство П. Турана опиралось на недоказанную тогда гипотезу о плотности распределения нулей $L$-функций Дирихле с характерами по одному модулю в “критической” полосе. Ю. В. Линник доказал неравенство для $p(k, l)$ без использования этой гипотезы. Но его доказательство было сложным и трудоемким. К. А. Родосский нашел новое, более простое, доказательство этого неравенства. Это доказательство изложено в Х главе книги австрийского математика К. Прахара "Распределение простых чисел", переведенной на русский язык в 1967 г. Второе доказательство теоремы Ю. В. Линника через семь лет было получено П. Тураном.

Особый интерес у специалистов по теории чисел вызвала работа "Об исключительном нуле", в которой было получено наиболее простое доказательство знаменитой теоремы немецкого математика K. Зигеля об исключительном нуле $L$-функций.

В дальнейшем К.А. Родосский выполнил ряд работ, в которых применялся один из двух аналитических методов: метод преобразования "нагруженных сумм" и метод преобразования производящих функций с помощью интеграла, выражающего нормальное распределение вероятностей. С помощью своего первого метода К. А. Родосскому удалось существенно улучшить оценки некоторых тригонометрических сумм. Второй метод в дальнейшем эффективно использовал в своих работах венгерский математик И. Катаи. К. А. Родосским были решены некоторые задачи целочисленного программирования, которые возникли в теории денежного обращения и были поставлены профессором Саратовского экономического института П. А. Парфаньяком еще в 1947 г.

В 70-е годы К. А. Родосский занялся проблемами теории евклидовых колец и проблемами факторизации в коммутативных кольцах. Результаты многолетних исследований были изложены в монографии “Алгоритм Евклида". В ней, впервые в мировой математической литературе, систематически изложена теория классических евклидовых колец с приложениями к системам линейных уравнений и линейных сравнений над евклидовыми кольцами.

Большое внимание К. А. Родосский уделял педагогической работе. Он был блестящим преподавателем. Лекции, прочитанные им, надолго оставались в памяти его 
учеников. Он читал лекции по линейной алгебре, теории чисел и математической логике и различные спецкурсы, руководил научной работой студентов, аспирантов и преподавателей. В 1973 г. Кирилл Андреевич был награжден почетной грамотой Министерства просвещения РСФСР и Республиканского комитета профессионального союза работников высшей школы и научных учреждений РСФСР.

К. А. Родосский выполнял большую общественную работу. Он был ответственным редактором межвузовского сборника работ по теории чисел, являлся членом Ученого Совета ГУВУЗ МП РСФСР, по просьбе издательства "Просвещение" и Математического института АН СССР рецензировал статьи и книги.

Кирилл Андреевич Родосский был исключительно благородным, интеллигентным и мужественным человеком и доброжелательным к людям. Светлая память о нем навсегда сохранится в сердцах окружавших его людей.

Р.А. Архонтова, А.Г. Баскаков, И.А. Бахтин, Э.С. Беляева, Ю.Г. Борисович, А.С. Греченко, В.Р. Зачепа, А.А. Карачуба, А.Ф. Кудинов, В.В. Обуховский, А.И. Перов, А.С. Потапов, Е. М. Семенов, В.П. Трофимов, Н. Н. Удоденко 